\title{
PENINGKATAN KOMPETENSI MENIMBANG DENGAN NERACAANALITIS MELALUI MODEL PEMBELAJARAN TEAM ASSISTE INDIVIDUALIZATION (TAI) PADA SISWA KELAS X KI A SMK NEGERI 2 SUKOHARJO SEMESTER 1 TAHUN PELAJARAN 2019/2020
}

\author{
Teguh Pangajuanto, S.Pd \\ SMK Negeri 2 Sukoharjo, Teguh Pangajuanto,S.Pd, Sukoharjo, Kodepos 57515 \\ Email Korespondensi : teguhpangajuanto@gmail.com
}

Diajukan: 1 January 2020; Diterima: 2 February 2020; Diterbitkan: 30 April 2020

\begin{abstract}
Abstrak: Peningkatan Kompetensi Menimbang dengan Neraca Analitis Melalui Model Pembelajaran Team Assisted Individualization (TAI) pada Siswa Kelas X KI A SMK Negeri 2 Sukoharjo Semester 1 Tahun Pelajaran 2019/ 2020. Penelitian Tindakan Kelas (PTK) SMK Negeri 2 Sukoharjo. Penelitian ini bertujuan untuk meningkatkan : (1) aktivitas siswa dalam pembelajaran menimbang dengan neraca analitis (2) kompetensi menimbang dengan neraca analitis, (3) perubahan perilaku siswa yang menyertai peningkatan kompetensi melalui model pembelajaran Team Assisted Individualization (TAI) pada siswa Kelas X KI A SMK Negeri 2 Sukoharjo. Penelitian ini merupakan Penelitian Tindakan Kelas (PTK). Sebagai tindakannya adalah penerapan model pembelajaran Team Assisted Individualization pada materi penimbangan dengan neraca analitis. Penelitian dilaksanakan dalam dua siklus, dengan tiap siklus terdiri atas perencanaan, pelaksanaan tindakan, pengamatan dan refleksi. Subyek penelitian adalah siswa kelas X KI A SMK Negeri 2 Sukoharjo tahun pelajaran 2019/ 2020 . Sumber data berupa kegiatan pembelajaran, kolaborator dan dokumen. Data diperoleh melalui observasi, tes tertulis dan praktik, dan kajian dokumen. Teknik analisis data yang digunakan adalah analisis deskriptif kualitatif. Hasil penelitian menunjukkan bahwa penerapan model pembelajaran Team Assisted Individualization dapat meningkatkan aktivitas dan kompetensi siswa pada materi penimbangan dengan neraca analitis kelas $\mathrm{X}$ KI A SMK Negeri 2 Sukoharjo tahun pelajaran 2019/2020. Hal tersebut dapat dilihat dari aktivitas siswa yang semula terlalu lama menunggu giliran menimbang menjadi $100 \%$ siswa memperhatikan dan berlatih menimbang, serta terjadi peningkatan persentase ketercapaian aspek pengetahuan pada siklus I sebesar $85,20 \%$ menjadi 93,88\% pada siklus II dan kompetensi aspek keterampilan seluruh(100\%) siswa kompeten dengan tingkat ketercapaian 97,94\%. Simpulan penelitian ini adalah penerapan model pembelajaran Team Assisted Individualization (TAI) dapat meningkatkan aktivitas, kompetensi dan perilaku siswa dalam penimbangan dengan neraca analitis kelas X KI A SMK Negeri 2 Sukoharjo.
\end{abstract}

Kata kunci : aktivitas, kondusif, hasil belajar, perubahan perilaku

Abstract: Improving Weighing Competence with Analytical Balance Through the Team Assisted Individualization (TAI) Learning Model for Class X KI A Students of SMK Negeri 2 Sukoharjo Semester 1 of the 2019/2020 Academic Year. Classroom Action Research (CAR) SMK Negeri 2 Sukoharjo. This study aims to improve: (1) student activities in learning to weigh with an analytical balance (2) competence to weigh with an analytical balance, (3) changes in student behavior that accompanies increasing competence through the Team Assisted Individualization (TAI) learning model in Class X KI students. A SMK Negeri 2 Sukoharjo. This research is a Classroom Action Research (CAR). The action is the application of the Team Assisted Individualization learning model on weighing materials with analytical balances. The research was carried out in two cycles, with each cycle consisting of planning, implementing actions, observing and reflecting. The research subjects were students of class X KI A at SMK Negeri 2 Sukoharjo in the 2019/2020 school year. Sources of data in the form of learning activities, collaborators and documents. Data were obtained through observation, written and practical tests, and document review. The data analysis technique used is descriptive qualitative analysis. The results showed that the application of the Team Assisted Individualization learning model could increase student activity and competence in weighing material with analytical balances for class X KI A SMK Negeri 2 Sukoharjo in the 2019/2020 school year. This can be seen from the activities of students who initially waited too long for their turn to weigh. to $100 \%$ students pay attention and practice weighing, and there is an increase in the percentage of achievement of the knowledge aspect in the first cycle by $85.20 \%$ to $93.88 \%$ in the second cycle and the competence of all skills aspects (100\%) of competent students with an achievement level of $97.94 \%$. The conclusion of this study is that 
the application of the Team Assisted Individualization (TAI) learning model can increase students' activities, competencies and behavior in weighing with analytical balances for class X KI A SMK Negeri 2 Sukoharjo.

Keywords: activity, conducive, learning outcomes, behavior change

\section{Pendahuluan}

Pembelajaran Teknik Dasar Pekerjaan Laboratorium Kimia memerlukan ketrampilan dari seorang guru agar siswa mudah memahami materi yang diberikan. Pada pembelajaran ini terdapat materi penimbangan dengan neraca analitik yang sangat esensial esensial karena erat kaitannya dengan materi yang lain seperti pembuatan larutan, analisis volumetri, analisis gravimetri serta banyak pelajaran lain yang memerlukan keterampilan menimbang dalam praktinya. Hal ini menuntut siswa harus benar-benar kompeten dalam materi penimbangan baik pengetahuan maupun keterampilan menimbang. Untuk itu diperlukan berbagai inovasi dalam proses belajar mengajar untuk menghasilkan situasi belajar mengajar yang kondusif agar tujuan pembelajaran dapat tercapai. Oleh karena itu, keterampilan dan kreativitas dari guru maupun dari siswa sangat diperlukan untuk mencapai hasil yang maksimal dalam dunia pendidikan, karena pada dasarnya keberhasilan dalam suatu pembelajaran sangat dipengaruhi oleh kolaborasi antara siswa dengan guru. Keduanya harus bisa saling berkolaborasi untuk bisa menciptakan suasana belajar yang menyenangkan sehingga dapat membangkitkan semangat belajar dan mendorong peserta didik untuk memperoleh prestasi yang baik. Kolaborasi siswa dengan guru pada pembelajaran penimbangan dengan neraca analitik sangat dipengaruhi oleh ketersediaan neraca analitik. Pada tahun 2019 laboratorium kimia industri SMK Negeri 2 Sukoharjo baru memiliki 2 neraca analitik. Hal ini belum sebanding dengan jumlah siswa yang rata-rata 36 siswa tiap kelas. Oleh karena itu agar semua siswa secara individu kompeten dalam penimbangan dengan neraca analitik maka diperlukan model pembelajaran yang tepat.

Terdapat beberapa penelitian yang

telah dilakukan menggunakan model pembelajaran kooperatif tipe Team Assisted Individualization (TAI), antara lain penelitian Vitria (2014) dan Sari (2017) yang menunjukkan bahwa penerapan model TAI dapat meningkatkan prestasi belajar.
Berdasarkan latar belakang di atas, maka penulis merumuskan masalah dalam penelitian ini adalah sebagai berikut: (1) Bagaimanakah proses pembelajaran menggunakan model Team Assisted Individualization (TAI) pada materi penimbangan dengan neraca analitis siswa kelas X KI A SMK Negeri 2 Sukoharjo ? (2) Apakah penerapan model pembelajaran Team Assisted Individualization dapat meningkatkan kompetensi siswa pada materi penimbangan dengan neraca analitis kelas X KI A SMK Negeri 2 Sukoharjo ? (3) Bagaimanakah perubahan perilaku siswa kelas $X$ KI A SMK Negeri 2 Sukoharjo yang menyertai peningkatan kompetensi penimbangan dengan neraca analitis menggunakan model pembelajaran Team Assisted Individualization ?

Sejalan dengan perumusan masalah yang telah dikemukakan, maka penelitian ini bertujuan untuk meningkatkan : (1) Aktivitas siswa dalam pembelajaran penimbangan dengan neraca analitis kelas X KI A SMK Negeri 2 Sukoharjo. (2) Kompetensi siswa dalam pembelajaran penimbangan dengan neraca analitis kelas X KI A SMK Negeri 2 Sukoharjo. (3) Perubahan perilaku siswa kelas $X$ KI A SMK Negeri 2 Sukoharjo yang menyertai peningkatan kompetensi sisws dalam pembelajaran penimbangan dengan neraca analitis

\section{Metode Penelitian}

Penelitian tindakan kelas ini dilakukan di SMK Negeri 2 Sukoharjo pada Kelas X KI A semester 1 tahun pelajaran 2019/ 2020 pada mata pelajaran Teknik Dasar Pekerjaan Laboratorium Kimia yang berlangsung di laboratorium kimia.

Penelitian dilakukan selama empat bulan, yakni antara bulan Juli sampai dengan Oktober 2019 Subyek penelitian ini adalah siswa kelas X KI A tahun pelajaran 2019/ 2020.

Strategi yang dilakukan dalam penelitian ini adalah deskripstif kualitatif yaitu bertujuan untuk menggambarkan dan menjelaskan kenyataan yang ada. Peneliti mencoba memberikan gambaran dan menjelaskan semua 
kegiatan pelaksanaan tindakan kelas. Kenyataan yang dimaksud adalah proses pembelajaran penimbangan menggunakan neraca analitik sebelum dan sesudah diberi tindakan berupa penerapan model pembelajaran Team Assisted Individualization (TAI) .

Data dan sumber data yang digunakan dalam penelitian tindakan kelas ini antara lain :

Tempat dan peristiwa yang menjadi sumber data dalam penelitian yaitu kegiatan pembelajaran penimbangan neraca analitis dalam penelitian ini adalah siswa Kelas X KI A SMK Negeri 2 Sukoharjo.

Dokumen yang berupa Rencana Pelaksanaan Pembelajaran (RPP), hasil belajar siswa berupa daftar nilai ulangan dan lembar jawab siswa, catatan lapangan selama pembelajaran berlangsung setiap siklus.

Teknik pengumpulan data pada penelitian ini dilakukan dengan cara observasi, tes, dan analisis data. Teknik analisis data dalam penelitian ini adalah teknik analisis kritis dan teknik analisis deskriptif komparatif. Analisis kritis berkaitan dengan data yang bersifat kualitatif. Data dalam analisis kritis berupa hasil observasi dan uji keterampilan. Teknik ini mencakup kegiatan untuk mengungkap kelemahan dan kelebihan kinerja siswa dan guru dalam proses belajar mengajar.

\section{Hasil Penelitian dan Pembahasan}

Dari hasil tes tertulis yang telah dikoreksi dan dianalisis diperoleh data hasil belajar aspek pengetahuan. Perbandingan hasil belajar aspek pengetahuan pada pra tindakan, siklus I dan siklus II dapat dilihat pada tabel berikut:

Tabel 4.2. Perbandingan hasil belajar Aspek Pengetahuan Siklus I dan Siklus II.

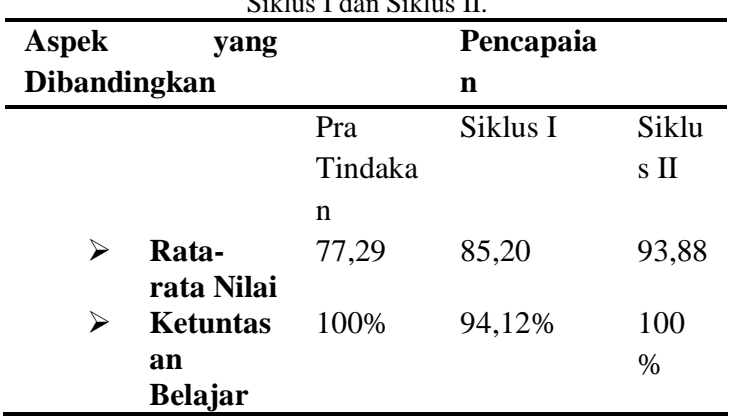

Dari tabel tersebut terlihat bahwa terjadi peningkatan nilai rata-rata dari 77,29 pada pra tindakan menjadi 85,20 pada siklus I dan 93,88 pada siklus II. Pada siklus I ketuntasan belajar baru mencapai $94,12 \%$ karena masih ada dua siswa yang belum kompeten pada materi tersebut dan harus dilakukan perbaikan pada siklus II. Setelah tindakan pada siklus II terjadi kenaikan nilai rata-rata dan juga ketuntasan belajar yaitu menjadi $100 \%$.

Hasil akhir penilaian aspek keterampilan didasarkan pada jumlah skor yang diperoleh siswa. . Hasil analisis prestasi belajar aspek keterampilan dapat dilihat pada Lampiran .. Dari hasil analisis penilaian kompetensi keterampilan siswa X KI A dapat disimpulkan bahwa sebesar $100 \%$ (seluruh siswa) mencapai nilai diatas 75 yang berarti seluruh siswa telah kompeten menimbang dengan neraca analitis. Hasil belajar siswa melalui tes siklus II dapat disajikan pada tabel 4.3 berikut.

Tabel 4.3. Hasil belajar siswa pada siklus II

\begin{tabular}{llccc}
\hline Aspek & $\begin{array}{c}\text { Indikato } \\
\text { r } \\
\text { keberha } \\
\text { silan }\end{array}$ & $\begin{array}{c}\text { Ketercap } \\
\text { aian }\end{array}$ & $\begin{array}{c}\text { Kriteria } \\
\text { keberha } \\
\text { silan }\end{array}$ \\
\hline & Aktivi & $80 \%$ & $100 \%$ & Berhasil \\
& tas & $85 \%$ & $93,88 \%$ & Berhasil \\
& $\begin{array}{l}\text { Penge } \\
\text { tahua }\end{array}$ & $80 \%$ & $97,94 \%$ & Berhasil \\
& & & \\
n & & & \\
Keter & & & \\
ampil & & & \\
an & & & \\
\hline
\end{tabular}

Berdasarkan observasi pembelajaran awal pada materi penimbangan dengan neraca analitis mata pelajaran Teknik Dasar Pekerjaan Laboratorium Kimia, terdapat permasalahan yang dihadapi guru dalam proses pembelajaran. Guru merasakan bahwa untuk dapat membimbing siswa agar dapat terampil menimbang secara individu proses pembelajaran menjadi kurang kondusif karena Guru membimbing satu persatu siswa untuk menimbang sehingga siswa yang lain kurang pengawan. Selain itu penggunaan waktu menjadi tidak efisien karena siswa terlalu lama menunggu giliran dan pembimbingan tidak dapat selesai dalam satu pertemuan. Besarnya jumlah siswa dalam kelas juga menyebabkan sulitnya guru menjangkau dan memberikan bimbingan kepada siswa, terutama aspek keterampilan menimbang dengan neraca analitis.. Selain itu, minimnya buku pegangan siswa menjadi salah satu masalah yang besar bagi guru. Hal ini berdampak pada prestasi belajar siswa. Permasalahan tersebut perlu 
segera dicari solusinya. Salah satu cara yang dapat digunakan sebagai solusi yaitu penggunaan model pembelajaran agar siswa tidak terlalu lama menunggu giliran latihan menimbang. SMKN 2 Sukoharjo Khususnya paket keahlian Kimia Industri telah mempunyai fasilitas pembelajaran yang tersedia sudah cukup baik. Laboratorium Kimia Industri SMKN 2 Sukoharjo telah memiliki dua neraca analitis dan empat neraca yang pengoperasiannya seperti neraca analitis. Neraca tersebut dapat digunakan siswa untuk latihan menimbang, hanya saja perlu pembimbing tambahan, karena Guru tidak dapat sekaligus membimbing empat atau enam siswa dengan empat atau enam neraca. Berdasarkan permasalahan yang ada, dilakukan suatu tindakan untuk memperbaiki pembelajaran, yaitu dengan penerapan model pembelajaran TAI. Menurut Gillies (2003), model pembelajaran kooperatif dengan kelompok kecil memungkinkan adanya kerja sama, perasaan saling memiliki antar kelompok, dan saling membantu. Sehingga, model ini tepat digunakan untuk meningkatkan kemampuan siswa baik aspek pengetahuan maupun aspek keterampilan.Tindakan yang dilakukan pada kelas X KI A SMKN 2 Sukoharjo terdiri dari dua siklus. Siklus I dilaksanakan dalam waktu 2 pertemuan, dan diakhiri dengan adanya tes siklus I. Siklus II dilaksanakan dalam waktu 2 pertemuan, dan diakhiri dengan adanya tes siklus II. Pada awal pembelajaran, diadakan pembentukkan kelompok dimana masing-masing kelompok terdiri dari 8 dan 9 siswa secara heterogen. Sebelum pembelajaran dimulai, peserta didik yang berperan sebagai asisten memperoleh materi terlebih dahulu, sehingga lebih menguasai dibandingkan dengan temantemannya yang lain. Selanjutnya, asisten membantu guru membimbing teman-temannya dalam kelompok. Guru menekankan agar siswa aktif tanya jawab/berdiskusi dalam kelompok sehingga mampu menguasai materi pelajaran. Saat proses pembelajaran, guru melakukan observasi terhadap aktivitas siswa. Pada akhir pembelajaran siklus I, diadakan tes siklus I yang berupa tes pengetahuan. Dari hasil tes yang diikuti 34 siswa pada siklus I, siswa yang sudah kompeten sebanyak 32 siswa atau sebesar 94,12\% dan masih ada 2 siswa yang belum kompeten. Pada aspek keterampilan belum dilakukan karena untuk tes keterampilan secara individu selain memerlukan banyak waktu, siswa masih perlu latihan lagi untuk dapat kompeten dalam menimbang dengan neraca analitis. Tes aspek keterampilan dilakukan dengan tes praktik menimbang secara individu pada siklus II. Dari hasil observasi dan hasil belajar siswa pada siklus satu, masih diperlukan tindakan lebih lanjut agar siswa lebih kompeten baik dari aspek pengetahuan maupun keterampilan. Untuk memberikan tindakan lebih lanjut dilakukan serangkaian perencanaan untuk siklus II. Pada siklus II, guru meminta siswa untuk menanyakan tentang hal-hal yang belum dipahami berkaitan dengan neraca analitis. Pada siklus II Guru juga melanjutkan pembelajran berikutnya tetapi masih berkaitan dengan menimbang dengan neraca analitis, yaitu menimbang dengan neraca anlitis sesuai karakteritik sampel. Dengan demikian siswa akan lebih memahami dan lebih banyak belajar menimbang dengan neraca analitis. Dengan demikian, diharapkan siswa dapat berlatih mengerjakan soal sehingga memahami materi yang diajarkan. Pelaksaan pembelajaran pada siklus II, guru mengingatkan siswa untuk lebih aktif bertanya dan berlatih menimbang dengan neraca analitis.

Dari hasil observasi, terlihat siswa lebih mengenal neraca analitis baik bagianbagiannya juga fungsinya. Siswa juga lebih memahami langkah-langkah menimbang dengan neraca analitis serta mulai menyadari bahwa keterampilan menimbang diperoleh dengan banyak berlatih bukan menghafal langkah-langkahnya. Pada akhir siklus II dilakukan tes tertulis untuk mengetahui kompetensi dari aspek pengetahuan dan tes praktik untuk mengetahui kompetensi dari aspek keterampilan.Dari hasil tes tertulis yang telah dianalisis diperoleh hasil sebagai berikut : Semua (100\%) siswa yang mengikuti tes tertulis telah kompeten yaitu seluruh siswa mendapatkan nilai di atas kriteria ketuntasan minimal yaitu 75 dengan tingkat ketercapaian $93,88 \%$ yang telah melampaui indikator keberhasilan yaitu $85 \%$. Hasil tersebut juga menunjukkan terjadinya peningkatan rata-rata nilai dari 77,29 menjadi 85,20 pada siklus I dan 93,88 pada siklus II. Dari hasil tes praktik, semula masih ada dua siswa yang belum kompeten, kemudian diberi bimbingan lagi dan 
mengikuti tes praktik lagi. Setelah hasil penilaian dianalisis terlihat bahwa seluruh siswa telah kompeten menimbang dengan neraca analitis dengan tingkat ketercapaian 97,94\% yang telah melampaui indikator keberhasilan yaitu $80 \%$. Berdasarkan hasil tersebut dapat diketahui bahwa secara keseluruhan penelitian penerapan model Team Assisted Individualization (TAI) pada materi penimbangan dengan neraca analitis berhasil karena pada akhir penelitian semua kriteria keberhasilan yang ditetapkan telah terpenuhi yaitu dapat meningkatkan kualitas proses belajar interaksi sosial dan dapat meningkatkan kualitas prestasi belajar siswa meliputi aspek pengetahuan dan keterampilan. Hasil tindakan dan pembahasan dapat disimpulkan bahwa pembelajaran model TAI dapat meningkatkan aktivitas dan kompetensi siswa pada materi penimbangan dengan neraca analitis kelas X KI A SMKN 2 Sukoharjo semester 1 tahun pelajaran 2019/2020.

\section{Simpulan, Saran, dan Rekomendasi}

Berdasarkan hasil penelitian yang telah dideskripsikan dan dianalisis diperoleh simpulan berikut ini. (1) Pembelajaran penimbangan dengan neraca analitis dengan model Team Assisted Individualization pada siswa Kelas X KI A SMK Negeri 2 Sukoharjo semester 1 tahun pelajaran 2019/2020 dapat meningkatkan aktivitas siswa dan berlangsung kondusif serta efisien. (2) Penerapan model pembelajaran Team Assisted Individualization (TAI) dapat meningkatkan kompetensi siswa pada materi penimbangan dengan neraca analitis kelas X KI A SMK Negeri 2 Sukoharjo tahun pelajaran 2019/ 2020. Peningkatan kompetensi tersebut dapat dilihat dari rata-rata nilai atau persentase ketercapaian aspek pengetahuan yaitu $77,29 \%$ pada pra tindakan menjadi $85,20 \%$ pada siklus I dan $93,88 \%$ pada siklus II. (3) Perubahan perilaku siswa yang menyertai peningkatan kompetensi pada materi penimbangan dengan neraca analitis Kelas X KI A SMK Negeri 2 Sukoharjo semester 1 tahun pelajaran 2019/2020 ditandai dengan pembelajaran yang lebih kondusif dan jumlah siswa yang kompeten dari aspek keterampilan sebesar $100 \%$.

Berdasarkan hasil penelitian yang dilakukan, dapat dikemukakan implikasi bahwa secara teoritis, dapat digunakan sebagai dasar penelitian selanjutnya dan dapat digunakan untuk membantu siswa dalam meningkatkan proses dan hasil belajar Teknik Dasar Pekerjaan Laboratorium Kimia (TDPLK) secara optimal. Secara praktis berdasarkan hasil penelitian, metode pembelajaran kooperatif Team Assisted Individualization (TAI) dapat diterapkan pada pembelajaran mata pelajaran Teknik Dasar Pekerjaan Laboratorium Kimia untuk meningkatkan aktivitas dan kompetensi siswa pada materi penimbangan dengan neraca analitis.

Berdasar simpulan hasil penelitian dan implikasi di atas, dapat kami rekomendasikan kepada rekan-rekan guru sebagai berikut : (1) Untuk meningkatkan kompetensi keterampilan pada pembelajaran dengan jumlah siswa yang banyak akan lebih kodusif dan efisien dengan menerapkan model pembelajaran Team Assisted Individualization. (2) Agar seluruh siswa kompeten dari aspek keterampilan seperti menimbang dengan neraca analitis maka siswa harus dilatih secara individu, untuk dapat membimbing seluruh siswa perlu ditujuk asisten kelompok.

\section{DAFTAR PUSTAKA}

Anitah, Sri. 2009. Media Pembelajaran. Sukoharjo: LPP UNS dan UNS Press.

Arsyad, A. 2017. Media Pembelajaran. Jakarta: Rajawali Pers.

Azizhwati. $2010 \quad$ Penerapan Pendekatan Contextual Teaching Learning dalam Meningkatkan Keterampilan Psikomotorik Kimia Siswa di Kelas XI SMA Negeri I Ukui

Bakti Mulyani. 2014 dengan judul penelitian "Penerapan pendekatan Contextual Teaching And Learning (CTL) Disertai Praktikum Untuk Meningkatkan Aktivitas dan Prestasi Belajar kimia Pada MateriPokok Termokimia Kelas XI SMK Muhammadiyah 2 Sragen Tahun Pelajaran 2013/2014

Direktorat Pendidikan Sekolah Menengah Kejuruan Kementrian Pendidikan dan Kebudayaan Republik Indonesia. 2014. Teknik Dasar Pekerjaan Laboratorium Kimia. Jakarta. Kemendikbud

Indah Qorina. X9017018. Upaya Peningkatan Prestasi belajar \& Interaksi Sosial Menggunakan Model Pembelajaran Team Assisted Individualization (TAI) pada 
Materi Titrasi Asam Basa Kelas X KI B SMK N 2 Sukoharjo.

Lidinillah, Muis. 2009. Pengaruh media pembelajaran yang disajikan siswa Terhadap Hasil Belajar Perbaikan Casis Otomotif di SMK Negeri 2 Sukoharjo.

Nurhadi. 2002. Pendekatan Kontekstual. Jakarta: Depdiknas.

Sadiman, A. S. dkk. 2007. Media Pendidikan, Pengertian, Pengembangan dan Pemanfaatannya. Jakarta: PT Raja Grafindo Persada.

Sanjaya, Wina. 2007. Strategi Pembelajaran: Berorientasi Standar Proses Pendidikan. Jakarta: Prenada Media Group.
Sumantri, M. \& Permana, Jr. 2001. Strategi Belajar Mengajar. Bandung: CV Maulana.

Suwandi, S. 2005. Pendidikan (Suatu Pengantar). Sukoharjo: LPP dan UNS press.

Suyanti, Retno, Dwi. 2010. Strategi Pembelajaran Kimia. Yogyakarta : Graha Ilmu 2017. Model-Model Asesmen dalam Pembelajaran. Sukoharjo: Yuma Pustaka.

2017. Penelitian Tindak Kelas (PTK) dan Penulisan Karya Ilmiah.Sukoharjo: Yuma Pustaka.

Trianto. 2008. Media Pembelajaran kontekstual (Contekstual Teaching And Learning) di Kelas. Jakarta: Cerdas Pustaka Publisher. 